\title{
A Review of China- Pakistan Economic Corridor and Tourism Opportunities
}

\author{
Faiza Manzoor \\ Department of Agricultural Economics and Management \\ Zhejiang University \\ Hangzhou, China
}

\begin{abstract}
One Belt One Road is China initiative, its aims to create the world's largest platform for economic cooperation, including policy coordination, trade and financing collaboration, and social and cultural cooperation. OBOR is a modern equivalent, creating a network of railways, roads, pipelines, and utility grids that would link China and Central Asia, West Asia, and parts of South Asia. China-Pakistan Economic Corridor (CPEC) is a part of Belt and Road initiative, nearly 2,000-mile trade route that links China's Xinjiang province with Gwadar in Pakistan's Balochistan province, and is expected to boost trade through a network of highways, railways and improved infrastructure. CPEC is a beneficial opening for the tourism industry of Pakistan. CPEC is expected to be lucrative for tourism and travel in Pakistan. Improved roads, power infrastructure, and pipelines will make the pristine tourist spots accessible. CPEC will change Pakistan and the region for the development because it is a noteworthy transformative initiative in recent history and is an engine of shared dreams, common prosperity and win-win cooperation among countries. CPEC will change Pakistan's business and economic setting through infrastructure and transportation development, establishing special economic zones, promoting tourism, increasing trade and commerce. Being an ongoing project, with its soft and smooth accomplishment the people from both the countries are expected to gain substantial benefits through China Pakistan Economic Corridor.
\end{abstract}

Keywords-China-Pakistan Economic Corridor; Infrastructure development; Tourism industry; Tourist attractions; Economic growth introduction

\section{INTRODUCTION}

One Belt one Road (OBOR) is China initiative for interregional connectivity among different countries for enhancing trade, social-cultural ties and develop infrastructure, encouraging trade and economic activities (Fig. I), and it will provide a chance for enhancing the lives of billions of people [1]. The OBOR blueprint encompasses over 60 countries, which account for $60 \%$ of the world's population and a collective GDP equivalent to $33 \%$ of the world's wealth [2]. The OBOR project includes 6 corridors under two roads, the New Silk Road Economic Belt running west towards Europe through Russia and Central Asian and the 21st Century Maritime Road focuses on reaching Europe through South

\author{
Longbao Wei* \\ Department of Agricultural Economics and Management \\ Zhejiang University \\ Hangzhou, China \\ lbwei@zju.edu.cn
}

Asia and Southwest Africa. The 6 corridors demonstrated below run between (Fig. 2): China-Mongolia-Russia Economic Corridor (CMREC); New Eurasian Land Bridge (NELB); China-Central and West Asia Economic Corridor (CCWAEC); China-Indo-China Peninsula Economic Corridor (CICPEC); China-Pakistan Economic Corridor (CPEC); and Bangladesh-China-India-Myanmar Economic Corridor (BCIMEC) [3]. The economic corridors effectively constitute the framework of the OBOR initiative beyond China's borders [4].

China-Pakistan Economic Corridor (also known by the acronym CPEC) is a collection of infrastructure projects that are currently under construction throughout Pakistan [5]. It is an agreement to launch joint working group underneath the national reforms and development commission of China and Ministry of Planning, reforms, and development of Pakistan. This agreement is made to build a roadway from Kashgar (city of China) to newly developing Gwadar port (Pakistan, Balochistan Province) which helps China in their trade and Pakistan to give new infrastructure, development, and connection of rural areas of both the countries [6].

CPEC is one of the mega projects consisting of highways, railways, and pipelines. It is a 3,218-kilometer long route, to be built over next several years. With the completion of these projects, Pakistan would become a regional economic hub [7]. It would also help in boosting the confidence of investors not only from China but also from other parts of the world. Originally valued at $\$ 46$ billion, the value of CPEC projects is now worth $\$ 62$ billion [8].

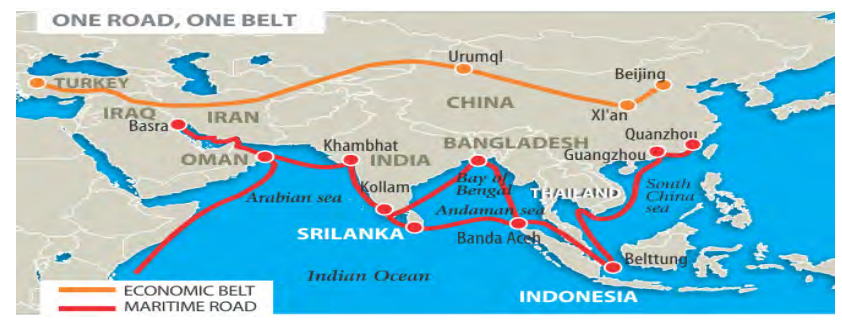

Fig. 1. source:https://cn.bing.com/images/search?view=detailV2\&ccid=LHI KaZPs\&id=816A9CC2F79E0AE7C310FA24A2384CBA51501F66\&thid=OI P.LHIKaZPsHht018XqbuDowQEsDU\&q 
THE SIX ECONOMIC CORRIDORS OF THE BELT AND ROAD

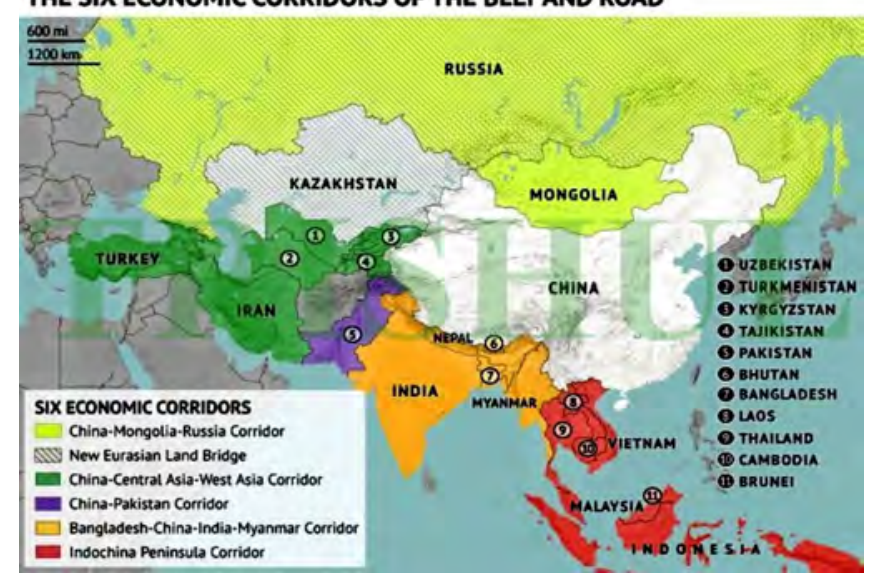

a. $\mathrm{CMREC}, \mathrm{NELB}, \mathrm{CCW} A E C$, CICPEC, CPEC, BCIMEC

Fig. 2. Source: China Investment Research.

Tourism is one of the important sectors for the growth of the country's economy [9]. The tourism industry continued to make a real difference to the lives of millions of people by driving growth, creating jobs, reducing poverty and fostering development and tolerance [10]. The tourism industry has contributed \$7.6 trillion to the global economy, which is $10.2 \%$ of the global GDP and generated 292 million jobs in 2016 [11]. With the recent investments in Gwadar port and the influx of Chinese investments through the CPEC, tourism within the country is expected to increase in the years ahead making it a very attractive hub for investments in the tourism and hotel business [12]. This project will develop the quality of tourism services, and would improve the services of public information; provide convenience in transportation, security protection and other services benefiting the public. It would strengthen social and economic development cooperation between Pakistan and China [13].

Local demand for traveling within Pakistan was increasing every year, with an expected number of over 50 million domestic tourists forecast by the Pakistan Tourism Development Corporation (PTDC), which shows a lot of potential in the industry [12].

\section{LITERATURE REVIEW}

Previous studies on CPEC discusses about job opportunities, trade, energy expansion, development of Gwadar port, good governance in Pakistan etc. Xie, [14] explained that this CPEC will boost investment opportunities for Pakistani entrepreneurs that will lead Pakistan toward Industrialization and development of under-developed parts of both the countries and also create new labor market for both moreover this ancient silk route will be revitalized with new opportunities for inhabitants of both the countries. Yunjiao, [15] described on the importance of energy cooperation between China Pakistan, CPEC will help to develop regional economies and strengthen energy sector too, a lot of things has been defined in CPEC but still with regard to energy cooperation the mechanisms are vague and there is need of improvement to institutionalize the cooperative mechanism moreover study says that Pakistan is at a good strategic location and this CPEC will help both the economies in different way. Butt et al., [16] explained that CPEC has the capacity to boost economic activities, increase trade linkages, enhance technical cooperation, generate new financial opportunities, and amplify socio-cultural connectivity among people in the region. The execution of this inclusive project would bring economic revolution that can transform the fate of the regional states in a positive way. This way CPEC has a greater regional and economic value as it would provide opportunity to all regional actors to make South Asia a seamless integrated region.

This paper is a review of CPEC and tourism opportunities via CPEC.

\section{TOURISM IN PAKISTAN}

The CPEC is not just name of a project but is a comprehensive package of cooperative initiatives and projects, which covered the key areas, including connectivity, information network, infrastructure, energy cooperation, industries and industrial parks, agricultural development and poverty alleviation, tourism, financial cooperation as well as livelihood improvement, municipal infrastructure, education, public health and people-to-people communication [17]. Hence, each side of the element fits in one of the key areas of the framework resulting in a community of shared destiny to ensure the perpetual continuity into the friendship of our two countries from generation to generation [18].

CPEC will also provide telecommunication and energy infrastructure to Pakistan to overcome the power crisis [19]. The project also includes the expansion of Karakoram Highway- the road that connects China with Pakistan and placement of fiber optics line, ensuring better communication between the two countries [20].

With more of the feasibilities, there will be a massive increase in the visitors to explore the spectacular landscapes. Proactively the Government of Azad Jammu and Kashmir has declared to make a tourism corridor in the valley [21]. Pakistan is home of most stunning Himalayan peaks, including K-2 and various magnificent valleys. It has beautiful the Arabian Sea, deserts, Indus valley, ancient Buddha's civilization carved in its mountains and historic forts. With all this, it is supposed to be one of the world's greatest tourist destinations [22].

Extracting from different references, Gilgit Baltistan is the hub of the tourism industry in Pakistan and attract millions of local and outland tourist. About 2.5 million tourists both domestic and international travelled to northern areas in Pakistan last year. Tourism is an important industry that will also see an immense boost as a result of CPEC progress in Pakistan [23]. Pakistan has the range of some of the highest mountains in the world, including $\mathrm{K} 2$, highly rich in landscape, mountains, glaciers, lakes, and valleys, and also boasts another five peaks above 8,000 meters, in addition to the more than 50 other mountains over 7,000 meters. Mountaineers from around the globe will flock to Pakistan as soon as CPEC is operational [24]. 


\section{A. Tourism Opportunities Through CPEC}

Chinese investors are keen to invest in the tourism sector of Pakistan as the CPEC projects will create new investment opportunities after the building of road and railways connectivity between the two countries. Increased connectivity after the development of rail and road links between Kashgar and Pakistan will be convenient for people to travel [25]. In 2015 alone, 30 million local and foreign tourists visited the scenic and historically and culturally rich Xinjiang province," "A delegation from Xinjiang province also visited GilgitBaltistan to explore opportunities for joint tourism and mutual businesses. The official said a big cultural park is under construction in the city where cultures and lifestyles of different countries, especially the members of Shanghai Cooperation Organisation (SCO) will be on the display. Pakistan has recently become a SCO's member. "Special efforts are being made to set up a Pakistani pavilion in the park where individuals, including cooks, singers and artisans will be brought from Pakistan and given employment [26].

Chinese tourists can access the 700-kilometer long coastal belt along the Arabian Sea through Kashgar-Gwadar road network planned under the CPEC. Currently, a bus service is operational from Gilgit-Baltistan to the Chinese border. From there onwards, transportation is available for Kashgar and Urumqi, the capital of Xinjiang. Kashgar and Urumqi are also connected via air routes and there are 12 flights on daily basis between the two cities [27]. A large number of people from Pakistan, especially businessmen visit Xinjiang. Urumqi is the first stop for goods coming from Central Asia to China. Being a Muslim majority province, Halal food is easily available, which can also promote tourism [26]. CPEC projects would increase job opportunities and tourism in Gilgit-Baltistan areas (Pakistan). Road infrastructure, hotels, health and other facilities would help improve the living standard of the people of the area [28].

\section{CONCLUSION}

An ambition of the One Belt One Road initiative is to increase connections between countries and people. Connectivity is about more than economic, financial and legal integration; it is also about interrelationships between cultures, and the connections that bind communities together. CPEC is one of great part of OBOR aim is to improve connectivity and economic development along route through the movement of goods, services, information and people and the exchange of culture. Linking Kashgar in Xinjiang with the deep-sea port of Gwadar in Pakistan, this corridor could afford China a shortcut to the Middle East and Africa via Dubai and Oman, bypassing the Strait of Malacca.

CPEC has been leaving motivational impacts on different sectors in Pakistan through its plentiful economic benefits and opportunities. CPEC is lucrative for and makes a conspicuous effect on the tourism industry in Pakistan. Furthermore reinforced roads, infrastructure, and pipelines will make the pure tourist spots accessible. Development of CPEC will lead to the development of infrastructure, which will also positively impact the tourism in Pakistan. It will develop the tourism industry in Pakistan. As Pakistan is full of natural beauty of
Swat, Naran, Kaghan, Murree, Deosai etc. and has diverse weather in it and the same time Chinese businessmen can be target market for tourist attraction on Silk Road. As more and new infrastructure of railways and roads will be developed it will not only enhance the trade but also boast the other things such as employment, tourism, development of rural areas and connection of rural areas to urban parts.

Hence as a concluding fact, it can be said that CPEC will open doors to immense economic opportunities not only in Pakistan but will physically connect China to its markets in Asia, Europe and beyond. It's a huge project that will lead to many different ways for a different sector, especially in tourism. By improving the security situation in the rest of the country and better infrastructure, tourism is expected to grow. CPEC is a worthwhile opportunity for the tourism industry of Pakistan. Pakistan should more focus on the importance of tourism through CPEC.

\section{REFERENCES}

[1] Yamei, Full text of President Xi's speech at opening of Belt and Road Forum. Xinhua News. Available at: http://news.xinhuanet.com/english/2017-05/14/c_136282982.htm, May 2017.

[2] Z. Huang, "your guide to understanding OBOR, Chinese's new silk road plan”. QUARTZ. Available at: https://qz.com/983460/obor-anextremely-simple-guide-to- understanding-chinas-one-belt-one-roadforum-for-its-new-silk-road/, May 2017.

[3] L. Bader, China's 6 Magical Economic Corridors. MarketMogul. Available at: https://themarketmogul.com/chinas-6-magical-economiccorridors/, August 2015.

[4] B. Jean-Marc F. and C. Flint, The Geopolitics of China's Maritime Silk Road Initiative, 2017, pp. 223-245.

[5] U.W. Chohan, What Is One Belt One Road? A Surplus Recycling Mechanism Approach, 2017.

[6] A. Syed. Ahtsham., J. Haider, M. Ali, S.I. Ali, and X. Ming, Emerging Tourism between Pakistan and China: Tourism Opportunities via ChinaPakistan Economic Corridor. International Business Research, 10(8), 204. 2017.

[7] M. Ibrar, J. Mi, and M. Rafiq, "China-Pakistan Economic Corridor: socio-cultural cooperation and its impact on Pakistan," EEM International Conference on Education Science and Social Science, 2016

[8] K. Khaleeq, "With a new Chinese loan, CPEC is now worth $\$ 62 \mathrm{bn}$. Available at: https://www.dawn.com/news/1287040, September. 2016.

[9] A. Xhiliola and M. Murati, "Tourism an important sector of economy development," Analele Universităţii Constantin Brâncuşi din Târgu Jiu: Seria Economie 1, vol. 1, pp. 83-90, 2015.

[10] M. Albert, "An analysis of tourism contribution to economic growth in SADC countries," Botswana Journal of economics 11, vol. 15, 2013.

[11] GTP. WTTC: Tourism Supports 1 in 10 Jobs, Outpacing Global Economy for 6th Year. Gtp headlines. Available at: https://news.gtp.gr/2017/03/20/wttc-tourism-supports-jobs-globaleconomy-6th-year/, March 2017.

[12] S. Reporter, CPEC to make Pakistan hub for investments in tourism, hotel businesses. Daily Time. Available at: https://dailytimes.com.pk/23568/cpec-to-make-pakistan- hub-forinvestments-in-tourism-hotel-businesses-wang/, March 2017.

[13] E. Tribune, CPEC will improve tourism service in the country. The Express Tribune. Available at: https://tribune.com.pk/story/1600802/2cpec-will-improve-tourism-services-country/, January 2018.

[14] X. Xie, C. Ma, and J. Li, "Research on employment Opportunities under theframework of China Pakistan Economic Corridor," International Conference on CPEC at GC University Lahore, December 2015. 
[15] Y. X. and Z. Guowei., Strengthening energy cooperation between China and Pakistan through CPEC. In Proceedings of International Conference on CPEC Held at GC University, Lahore 2015, (pp. 09-10)..

[16] K.M. Butt and A.A. Butt, "Impact of CPEC on Regional and ExtraRegional Actors," The Journal of Political Science, 33, 23, 2015.

[17] Z. Ruilian, F. Andam, and G.Q. Shi, "Environmental and social risk evaluation of overseas investment under the China-Pakistan Economic Corridor," Environmental monitoring and assessment 189, vol. 2017 (6), pp. 253.

[18] A. Ahmed, China Pakistan Economic Corridor. The new Silk Road. Reports.Available at: https://gulfnews.com/gn-focus/countryguides/reports/pakistan/china-pakistan-economic-corridor-the-new-silkroad-1.1998942, March 2017.

[19] K.S. Ahmad, "Geo-economic imperatives of Gwadar Sea Port and Kashgar economic zone for Pakistan and China," IPRI Journal 13, vol. 2013 (2), pp. 87-100.

[20] E. Hussain, CPEC effects on Tourism industry in Pakistan. Pakistan Tour \& Travel. Available

https://pakistantourntravel.com/2017/08/15/cpec-effects-on-tourismindustry-in-pakistan/, August 2017.
[21] M. Arshad, CPEC offers countless investment opportunities in tourism sector: Pakobserver. Available at: https://pakobserver.net/cpec-offerscountless-investment-opportunities-in-tourism-sector/, June. 2018.

[22] R.S. Ali and S.T. Jawaid, "Terrorism and tourism: A conjunction and ramification in Pakistan," Economic Modelling, vol. 2013 (33), pp. 65-70.

[23] B.Q. Bakhsh, "Managing tourism in Pakistan: A case study of Chitral valley," Journal of Managerial Sciences 2, vol. 2007 (2), pp.169-190.

[24] P. Press, CPEC to revitalize tourism. 4 traders. Available at: http://www.4- traders.com/news/CPEC-to-Revitalize-Tourism-25666604/, December 2017.

[25] K. Hussain. Exclisive: CPEC master plan revealed. DAWN, Available at: https://www.dawn.com/news/1333101, June 2017.

[26] S.I. Ahmed, "China keen to invest in tourism sector," Business. Available at: https:/www.thenews.com.pk/print/161336-China-keento-invest-in-tourism-sector.November 2017.

[27] S. Faheemullah, Q. Ji, and Y. Fan, "Prospects of Pakistan-China energy and economic corridor," Renewable and Sustainable Energy Reviews, vol. 2016 (59), pp.253-263.

[28] APP Corporation, CPEC to increase job opportunities, tourism in GilgitBaltistan. APP Corporation. Available at: http://www.app.com.pk/cpecto-increase-job- opportunities-tourism-in-gilgit-baltistan-cm/, June 2017. 